\title{
HLA Class I Histocompatibility Antigen, B-7 Alpha Chain
}

National Cancer Institute

\section{Source}

National Cancer Institute. HLA Class I Histocompatibility Antigen, B-7 Alpha Chain. NCI

Thesaurus. Code C62774.

HLA class I histocompatibility antigen, B-7 alpha chain protein (362 aa, $40 \mathrm{kDa}$ ) is encoded by the HLA-B gene. This protein is involved in the presentation of foreign antigens to the immune system. It is associated with susceptibility to ankylosing spondylitis, Behcet syndrome and carbamazepine-induced Stevens-Johnson syndrome. 